Karstenia 53: 5-8, 2013

\title{
Dianema corticatum new to Finland and contributions to the knowledge of Myxomycetes in the Åland Islands, SW Finland
}

\author{
PANU KUNTTU, ELINA VARIS and SANNA-MARI RIVASTO
}

\begin{abstract}
KUNTTU, P., VARIS, E. \& RIVASTO, S.-M. 2013: Dianema corticatum new to Finland and contributions to the knowledge of Myxomycetes in the Aland Islands, SW Finland. - Karstenia 53: 00-00. HELSINKI. ISSN 0453-3402.

In this paper we present Dianema corticatum as new to Finland and the second record of Hemitrichia abietina in Finland. Altogether we present 16 species of Myxomycetes new to the Åland Islands.
\end{abstract}

Key words: biogeography, Dianema corticatum, Myxomycetes, Åland Islands

Panu Kunttu, University of Eastern Finland, School of Forest Sciences. P.O. Box 111. FI-80101, Joensuu, Finland; e-mail: panu.kunttu@uef.fi

Elina Varis, Virontörmänkatu 1 D 18,FI-33310Tampere, Finland; e-mail: esivonen@, student.uef. $f i$

Sanna-Mari Rivasto, Hertsbölevägen 8 H 62, FI-25900 Dalsbruk, Finland; e-mail: sanna-mari.rivasto@iki.fi

\section{Introduction}

The first extensive publication of Finnish Myxomycetes by Härkönen \& Sivonen (2011) presented 204 species. One year later the authors wrote a new book where they list 213 species known in Finland (Härkönen \& Varis 2012). Knowledge about Myxomycetes in the Åland Islands is poor. At the time of writing the first checklist (Härkönen \& Sivonen 2011), there were only 10 species collected from the islands. The number of species rose rapidly when Panu Kunttu (PK) and Sanna-Mari Rivasto (S-MR) collected 26 myxomycete specimens during their field trip to the Åland Islands in August 2012. Ten new species to the Åland Islands emerged from this material: Arcyria affinis Rostaf., Arcyria pomiformis (Leers) Rostaf., Ceratiomyxa fruticulosa (O.F. Müll.) T. Macbr., Cribraria cancellata (Batsch) Nann.-Bremek., Cribraria vulgaris Schrad., Enerthenema papillatum (Pers.) Rostaf., Stemonitis axifera (Bull.) T. Macbr., Stemonitis fusca Roth, Stemonitopsis hyperopta (Meyl.) Nann.-Bremek. and Stemonitopsis reticulata (H.C. Gilbert) Nann.-Bremek. \& Y. Yamam. These are already presented in the book of Myxomycetes in Finland (Härkönen \& Varis 2012).

The Åland Islands are a large archipelago area between Finland and Sweden, situated in the middle of the Baltic Sea. The land area is approximately $1552 \mathrm{~km}^{2}$ and it comprises of 6757 islands and islets, eaxch of an area of at least 0.25 hectares (Åkerberg 2010). There are many special features in the nature of the Alland Islands: the growing season is long (195 days) and the diversity of biotopes is broad. Herb-rich forests are common, wood pastures and semi-natural woodlands and meadows are still commonly grazed by domestic animals. The tree species diversity is the highest in Finland. Compared to the forests of other areas in Southern Finland, the largest volume of dead wood has been measured in the 
forests of the Åland Islands, (Finnish Forest Research Institute 2012).

\section{Material and methods}

The material was collected as part of the biogeographical and ecological inventory on Myxomycetes in the Åland Islands. These islands constitute their own biogeographic province (Ahvenanmaa, Alandia) and it is located in the hemiboreal zone (Knudsen \& Vesterholt 2012). PK and S-MR spent 5.-7.X.2012 sampling the specimens. They collected 109 specimens of myxomycetes. An inventory was made by the method of opportunistic sampling of species (Stokland \& Sippola 2004). The main goal was to collect as many different species as possible in different kinds of biotopes. Specimens were identified mainly by Elina Varis, and Marja Härkönen gave remarkable help. Voucher specimens are deposited in the Herbarium of Turku University (TUR). The Finnish national uniform grid system $27^{\circ} \mathrm{E}$ (Uniform Coordinate System) is according to Heikinheimo \& Raatikainen (1981). Nomenclature is according to Härkönen \& Varis (2012). The decay stage classification (1-5) of trunks is according to Renvall (1995).

Prästgårdsnäset in Finström and Nåtö in Lemland are herb-rich forests dominated mainly by Corylus avellana and Quercus robur. Other common tree species are Fraxinus excelsior, Betula pendula and Pinus sylvestris. In Nåtö old trees of Picea abies can also be found. The vegetation is diverse and it contains many rare and specialized vascular plant species. The area of Prästgårdsnäset is 33 hectares and that of Nåtö is ca 30 hectares and these are managed by grazing of sheep and cows (Kulves 2004). These kinds of herb-rich forests of hardwood tree species are very rare biotopes in Finland.

Långmo in Eckerö is a Picea abies dominated old-growth forest. The area of this forest is ca 10 hectares and it lies in the middle of commercially managed forestry area. This forest contains many structures which are typical to forests in a natural state, like large amounts of dead wood, diversity of tree species, ground without human disturbance and a well preserved brook and patches of spruce mire. Uddhagarna in Eckerö is a relatively old coniferous forest with a brook where deciduous trees grow (Alnus glutinosa and Betula sp.) around it. The forest is located next to a small rich fen.

\section{Results and discussion}

The Åland Islands are a biogeographically inadequately known part of Finland because of its somewhat remote location from the continental part of Finland. In general, occurrence of Myxomycetes is poorly known in many other parts of Finland as well. There are only a few mycologists in Finland who are specialising on
Myxomycetes which limits the accumulation of knowledge regarding their distribution. Including the previous records cited in this paper, there are now 41 species of Myxomycetes found in the Alland Islands. Comparing this amount of species to other biogeographic provinces in Southern Finland, it is obvious that many more species will be found there.

\section{List of species}

Arcyria ferruginea Saut.

Specimen examined: Eckerö, Skeppsvik, Långmo, grid 6697922:3086979, on a fallen trunk of Picea abies (diam $30 \mathrm{~cm}$, decay stage 1) in a Picea abies dominated OxalisMyrtillus type forest, 6.X.2012 Kunttu 7784.

\section{Arcyria incarnata (Pers.) Pers.}

Specimens examined: Lemland, Nåtö, Själskata, grid 6680:3109, on Betula pendula (diam $45 \mathrm{~cm}$, decay stage 3) in a deciduous tree dominated herb-rich forest, 5.X.2012 Kunttu 7765. Eckerö, Skeppsvik, Långmo, grid 6697922:3086979, on Betula sp. (diam. $20 \mathrm{~cm}$, decay stage 4) in a Picea abies dominated Oxalis-Myrtillus type forest, 6.X.2012 Kunttu 7821.

Arcyria stipata (Schwein.) Lister

Specimen examined: Lemland, Nåtö, Själskata, grid 6680:3109, on a fallen trunk of Picea abies (diam $30 \mathrm{~cm}$, decay stage 4), in a deciduous tree dominated herb-rich forest, 5.X.2012 Kunttu 7766.

Dianema corticatum Lister - Fig. 1

Specimen examined: Eckerö, Skeppsvik, Långmo, grid 6697922:3086979, on a fallen trunk of Pinus sylvestris (diam $12 \mathrm{~cm}$, decay stage 3), in a Picea abies dominated Oxalis-Myrtillus type forest, 6.X.2012 Kunttu 7809.

This species is new to Finland. It was found for the first time on rotten planks at Sande, Norway in 1894 (Lister 1894). Since then it has been found in many Eurasian countries (for example Spain, Austria, Turkey and Russia), USA, Mexico and Australia (Neubert et al. 1993, Lizárraga et al. 2005, Ocak \& Hasenekoğlu 2005, Novozhilov et al. 2006, Lado \& Ronikier 2008). D. corticatum is widespread but uncommon (Poulain et al. 2011). D. corticatum grows usually on dead wood, generally on conifers (Poulain et al. 2011). Specimens have been collected from different kinds of habitats; including different tree species, mountain areas and occurring with thawing snow and furthermore obtained in moist chamber cultures (Lizárraga et al. 2005, Novozhilov et al. 2006, Lado \& Ronikier 2008).

Fuligo leviderma $\mathrm{H}$. Neubert, Nowotny \& K. Baumann Specimen examined: Lemland, Nåtö, Själskata, grid 


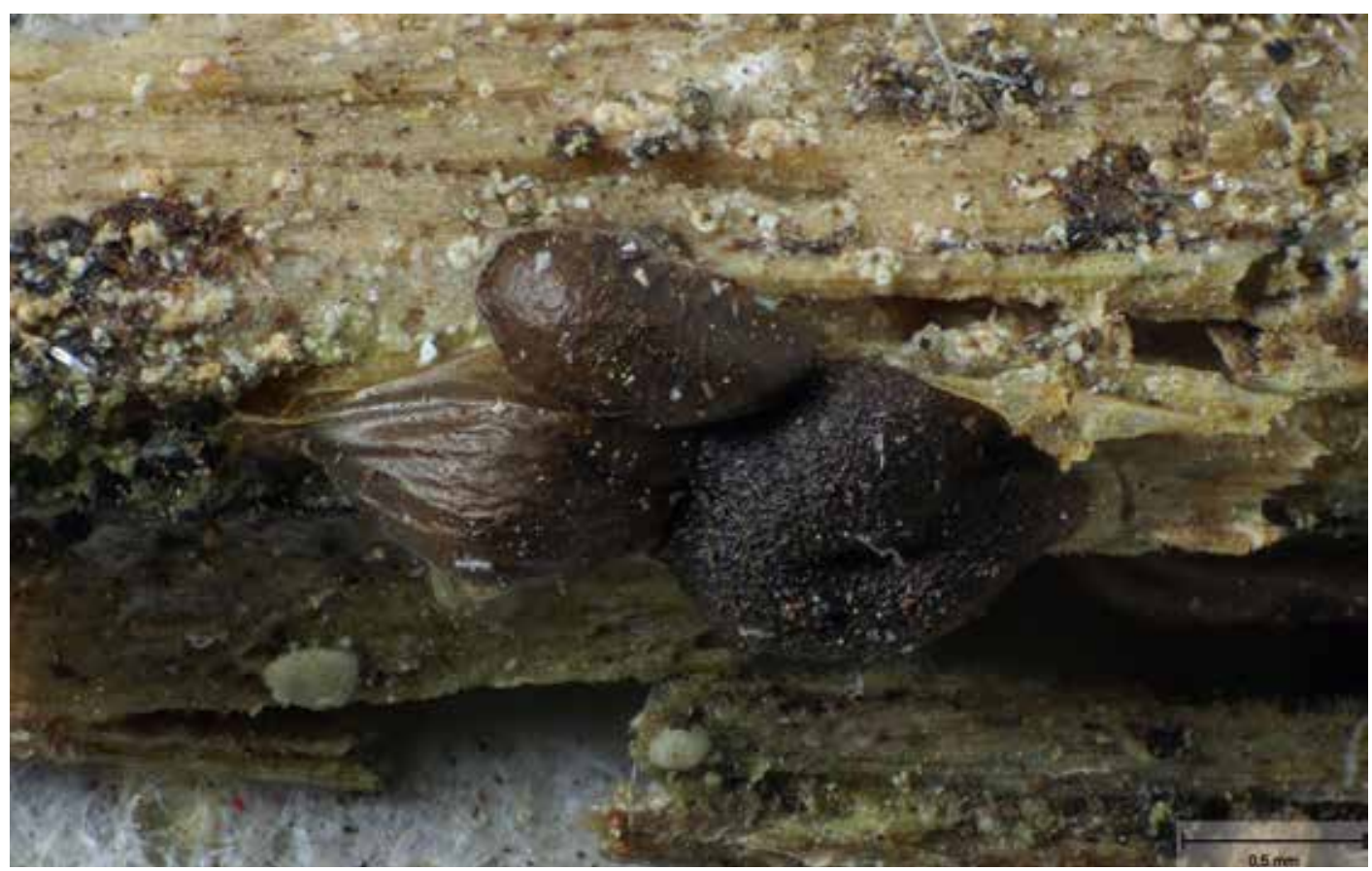

Fig. 1. Dianema corticatum. Photo: Mikael Kukkonen

6680:3109, on a fallen trunk of Alnus glutinosa (diam 40 $\mathrm{cm}$, decay stage 1), in a deciduous tree dominated herbrich forest, 5.X.2012 Kunttu 7756.

Fuligo muscorum Alb. \& Schwein.

Specimens examined: Eckerö, Skeppsvik, Långmo, grid 6697922:3086979, on moss, in a Picea abies dominated Oxalis-Myrtillus type forest, 6.X.2012, Kunttu 7812. Eckerö, Skeppsvik, Långmo, grid 6697922:3086979, on moss, in a Picea abies dominated Oxalis-Myrtillus type forest, 6.X.2012, Kunttu 7819.

\section{Hemitrichia abietina (Wigand) G. Lister}

Specimen examined: Lemland, Nåtö, Själskata, grid 6680:3109, on a fallen trunk of Picea abies, (diam $6 \mathrm{~cm}$, decay stage 3 ), in a deciduous tree dominated herb-rich forest, 5.X.2012 Kunttu 7757.

This is the second record in Finland. The first was collected as early as 1914 in Joroinen, Pohjois-Savo by T.J. Hintikka (Härkönen 1974).

Lamproderma arcyrioides (Sommerf.) Rostaf.

Specimen examined: Eckerö, Uddhagarna, grid 6695143:3087361, on a fallen trunk of Alnus glutinosa (diam $7 \mathrm{~cm}$, decay stage 2), in a Myrtillus type forest, 6.X.2012 Kunttu 7836.
Lamproderma columbinum (Pers.) Rostaf.

Specimen examined: Eckerö, Uddhagarna, grid 6695143:3087361, in a mossy and decayed stump (diam $25 \mathrm{~cm}$, decay stage 4), in a Myrtillus type forest, 6.X.2012 Kunttu 7847.

\section{Licea pusilla Schrad.}

Specimen examined: Lemland, Nåtö, Själskata, grid 6680:3109, on a fallen trunk of Picea abies (diam $30 \mathrm{~cm}$, decay stage 4), in a deciduous tree dominated herb-rich forest, 5.X.2012 Kunttu 7766.

Metatrichia vesparia (Batsch) Nann.-Bremek.

Specimen examined: Finström, Prästgårdsnäset, grid 6703:3109, on a fallen trunk of Betula sp. (diam $30 \mathrm{~cm}$, decay stage 4), in a Corylus avellana dominated herb-rich forest, 7.X.2012 Kunttu 7860.

\section{Physarum leucophaeum Fr.}

Specimens examined: Lemland, Nåtö, Själskata, grid 6680:3109, on a fallen trunk of Corylus avellana (diam $5 \mathrm{~cm}$, decay stage 3 ), in a deciduous tree dominated herbrich forest, 5.X.2012 Kunttu 7772. Eckerö, Uddhagarna, grid 6695143:3087361, on a fallen trunk of Betula sp. (diam $11 \mathrm{~cm}$, decay stage 3), in a Myrtillus type forest, 6.X.2012 Kunttu 7828 . 
Physarum notabile $\mathrm{T}$. Macbr.

Specimen examined: Finström, Prästgårdsnäset, grid 6703:3109, on a stump of Quercus robus (diam $100 \mathrm{~cm}$, decay stage 4), in a Corylus avellana dominated herb-rich forest, 7.X.2012 Kunttu 7877.

Reticularia jurana Meyl.

Specimen examined: Eckerö, Uddhagarna, grid 6695143:3087361, on a stump of probably Picea abies (diam $15 \mathrm{~cm}$, decay stage 2), in a Myrtillus type forest, 6.X.2012 Kunttu 7839.

\section{Trichia persimilis $\mathrm{P}$. Karst.}

Specimen examined: Finström, Prästgårdsnäset, grid 6703:3109, on a fallen trunk of Quercus robor, (diam 50 $\mathrm{cm}$, decay stage 1), in Corylus avellana dominated herbrich forest, 7.X.2012 Kunttu 7864.

Tubifera ferruginosa (Batsch.) J.F. Gmel. Specimens examined: Eckerö, Skeppsvik, Långmo, grid 6697922:3086979, on a stump of Alnus glutinosa (diam $19 \mathrm{~cm}$, decay stage 5), in a Picea abies dominated Oxalis-Myrtillus type forest, 6.X.2012 Kunttu 7787. Eckerö, Skeppsvik, Långmo, grid 6697922:3086979, on moss, in a Picea abies dominated Oxalis-Myrtillus type forest, 6.X.2012 Kunttu 7801.

Acknowledgements: We are grateful to docent Marja Härkönen (University of Helsinki) who helped to identify these specimens and who has given us a lot of inspiration to study Myxomycetes. Mikael Kukkonen is thanked for the excellent multi-layer photograph. Ernest Emmett is warmly thanked for checking the English language.

\section{References}

Finnish Forest Research Institute 2012: Finnish Statistical Yearbook of Forestry. 454 pp. Sastamala.

Heikinheimo, O. \& Raatikainen, M. 1981: Grid references and names of localities in the recording of biological finds in Finland. - Notulae Entomologicae 61: 133-154. [In Finnish with English summary]

Härkönen, M. 1974: Über die Finnischen Scleimpilzen. Karstenia 14: 54-81.

Härkönen, M. \& Sivonen, E. 2011: The Myxomycetes of Finland. - Norrlinia 22: 1-223 [In Finnish with English summary]

Härkönen, M. \& Varis, E. 2012: The Myxomycetes of Finland. - Norrlinia 25: 1-240. [In Finnish with English summary]

Knudsen, H., \& Vesterholt, J., (eds) 2012: Funga Nordica. Agaricoid, boletoid, clavarioid, cyphelloid and gasteroid genera. - 1083 pp. Nordsvamp. Copenhagen.

Kulves, H. 2004: Skyddad natur på Åland - ett arv att värna. - 272 pp. PQR-Kultur. Estland.

Lado, C. \& Ronikier, A. 2008: Nivicolous myxomycetes from the Pyrenees: notes on taxonomy and species diversity. Part 1. Physarales and Trichiales. - Nova Hedwigia 87: 337-360.

Lister, A. 1894: A monograph of the Mycetozoa. - 224 pp. The British Museum. London.

Lizárraga, M., Moreno, G., Illana, C. \& Singer, H. 2005: Myxomycetes from Chihuahua, Mexico III. - Mycotaxon 93: 75-88.

Neubert, H., Nowotny, W. \& Baumann, K. 1993: Die Myxomyceten Deutchlands und des angrenzenden Alpenraumes unter besonderer Berücksichtigung Österreichs 1. Ceratiomyxales, Echinosteliales, Liceales, Trichiales. -343 pp. Karlheinz Baumann Verlag. Gomaringen.

Novozhilov, Y. K., Zemlianskaia, I. V., Schnittler, M. \& Stephenson, S. L. 2006: Myxomycete diversity and ecology in the arid regions of the Lower Volga River Basin (Russia). - Fungal Diversity 23: 193-241.

Ocak, Ü. \& Hasenekoğlu, Ü. 2005: Myxomycetes from Trabzon and Giresun Provinces (Turkey). - Turkish Journal of Botany 29: 11-21.

Poulain, M., Meyer, M. \& Bozonnet, J. 2011: Les Myxomycètes. 1 \& 2. -568 pp. Fédération Mycologique et Botanique Dauphiné-Savoie. Sevrier.

Renvall, P. 1995: Community structure and dynamics of wood-rotting Basidiomycetes on decomposing conifer trunks in Northern Finland. - Karstenia 35: 1-51.

Stokland, J. N. \& Sippola, A.-L. 2004: Monitoring protocol for wood-inhabiting fungi in the Alberta Biodiversity Monitoring Program. - $58 \mathrm{pp}$. Report for the Alberta Biodiversity Monitoring Program.

Åkerberg, I. (ed.) 2010: Statistical Yearbook of Åland 2010. - 249 pp. Ålands statistik- och utredningsbyrå. Mariehamn. 